Acta vet. scand. $1969,10,195-196$.

Brief communication

\title{
CASES OF PSEUDORABIES IN FREE-LIVING RED FOXES (VULPES VULPES) AND IN GAPTIVE BLUE FOXES (ALOPEX LAGOPUS) IN DENMARK
}

In the period December 1967 through April 1969 eight spontaneous cases of pseudorabies in Danish red foxes were demonstrated by virus isolation. One fox had been kept in captivity, the remaining seven were free-living. Five of the foxes were found dead, while three, presenting abnormal behaviour when encountered, had been killed.

In September and October 1968 two outbreaks of pseudorabies occurred in blue foxes on fur farms. On the first farm 26 out of 34 foxes died, on the second two out of eight.

In six of the red foxes, lesions of the skin and underlying tissues indicative of self-mutilation due to pruritus were found in the head, most often localized to the region of the cheek, lips, and labial commissure on one side. In one fox a similar small skin lesion was observed on the tail, while in one which was killed no traumatic skin lesions were present at all.

According to the owners' information all the affected blue foxes had shown symptoms of pruritus localized to the head. Autopsy revealed traumatic lesions of the head in six of the foxes submitted to the laboratory, and pseudorabies virus was isolated from all of these six foxes.

The confined red fox, and the blue foxes, had been fed dead piglets deriving from stocks of pigs affected by pseudorabies, and these piglets undoubtedly constituted the source of infection in these cases.

As regards the cases in free-living red foxes there were good reasons to suspect that at least some of these could be attributed to consumption of material picked up from dunghills of farms with pseudorabies infection among the pigs.

No other reports on pseudorabies in free-living red foxes seem to have been published so far, and outbreaks of the disease on fur farms have not been demonstrated previously in Denmark. 
In a following publication case-histories, post-mortem findings, and sources of infection will be dealt with in greater detail, and virological investigations with special reference to routine diagnosis of pseudorabies in carnivores by tissue culture methods will be described.

V. Bitsch, Betty Knox and Bente Munch The State Veterinary Serum Laboratory, Copenhagen, Denmark.

(Received May 9, 1969). 